\title{
Coronavirus pandemic (COVID-19) and its natural environmental impacts
}

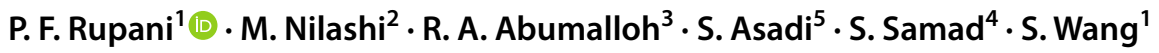

Received: 21 May 2020 / Revised: 28 July 2020 / Accepted: 24 August 2020 / Published online: 1 September 2020

(c) Islamic Azad University (IAU) 2020

\begin{abstract}
Coronavirus Disease 2019 (COVID-19) is the official name of a respiratory infectious disease caused by a new coronavirus that started first in Wuhan, China, and outspread worldwide with an unexpectedly fast speed. Flights have been canceled worldwide and transportation has been closed nationwide and across international borders. As a consequence, the economic activity has been stopped and stock markets have been dropped. The COVID-19 lockdown has several social and economic effects. Additionally, COVID-19 has caused several impacts on global migration. On the other hand, such lockdown, along with minimal human mobility, has impacted the natural environment somewhat positively. Overall carbon emissions have dropped, and the COVID-19 lockdown has led to an improvement in air quality and a reduction in water pollution in many cities around the globe. A summary of the existing reports of the environmental impacts of COVID-19 pandemic are discussed and the important findings are presented focusing on several aspects: air pollution, waste management, air quality improvements, waste fires, wildlife, global migration, and sustainability.
\end{abstract}

Keywords Coronavirus pandemic $\cdot$ Environmental impacts $\cdot$ Air pollution $\cdot \mathrm{CO}_{2}$ emissions $\cdot$ Economics

\section{Introduction}

COVID-19, which is the new coronavirus causing uncommon pneumonia, outspread in Wuhan, China on December 31, 2019 (Kavanagh 2020; Wu et al. 2020; Zhu et al. 2020). Since then, the national and international spread of the disease has threatened people's lives all around the world $(\mathrm{Wu}$

Editorial responsibility: Samareh Mirkia.

M. Nilashi

mehrbakhshnilashi@duytan.edu.vn

1 School of Energy and Power Engineering, Jiangsu University, Zhenjiang 212013, China

2 Institute of Research and Development, Duy Tan University, Da Nang 550000, Vietnam

3 Computer Department, Community College, Imam Abdulrahman Bin Faisal University, P.O. Box. 1982, Dammam, Saudi Arabia

4 Department of Business Administration, College of Business and Administration, Princess Nourah bint Abdulrahman University, Riyadh, Saudi Arabia

5 Faculty of Information Science and Technology, Universiti Kebangsaan Malaysia, 43600 Bangi, Selangor, Malaysia et al. 2020; Zhou et al. 2020). The early cases of human infection with COVID-19 in Wuhan were associated with big seafood and live animal markets, which indicated the transmission of the virus from animals to humans. Soon after, several people who had not been exposed to animals, were infected by the disease, which indicated the virus transmission from one individual to another. The disease spread was observed out of Chinese borders, almost in all countries over the world (Tahir and Batool 2020). 
According to official reports, human-to-human transmission is continuing nationally (Yang et al. 2020). Moreover, obvious community outspread to other regions is still occurring, which means infection of individuals without knowing the exact way, time, or place of infection. Transmission of the virus to Italy, Iran, South Korea, and many other countries has led epidemiologists to the belief that the virus cannot be restricted by Chinese borders and will soon outspread to other regions across the globe (Kanniah et al. 2020). As of 28th of August 2020 (www.bloomberg.com/graphics/2020coronavirus-cases-world-map/\#global-new-cases), coronavirus pandemic has infected more than 24,373,497 people and killed more than 830,518 worldwide since late January (see Fig. 1).

COVID-19 pandemic has impacted every aspect of the human life and the global economy (Klemeš et al. 2020). The global response to the pandemic of COVID-19 has led to unexpected reductions in economic activity and stock markets (Nilashi et al. 2020). Chinese authorities shut down transportation and travel in and out of Wuhan. To reduce disease spread, they established many quarantine rules, cut and reduced local business travels, closed schools, colleges, and universities (Wilder-Smith and Freedman 2020). Flights have been canceled worldwide and transport systems have been closed.
Apart from the negative social and economic impacts of COVID-19 lockdown (Hakovirta and Denuwara 2020), the quarantine regulations brought several environmental positive changes in several countries. For instance, a vital drop in air contamination has been indicated (Kanniah et al. 2020). The decrease of $\mathrm{NO}_{2}$ levels has been observed in many countries (Shrestha et al. 2020; Tobías et al. 2020; Wang and $\mathrm{Su} 2020$ ). The impact of COVID-19 on the improvement of water bodies was noticed, such as the improvement of Ganga river in India, as reported by Lokhandwala and Gautam (2020). Additionally, the lockdown rules have led to a release of human-dominated areas to be free for wildlife movement. On the other hand, each of the mentioned environmental factors can have a direct or indirect impact on controlling the disease. A study by Lal et al. (2020), suggested that there is a direct influence of humidity, air pollution, and temperature on the coronavirus expansion.

To date, limited studies have explored the influence of the COVID-19 crisis on the environment in several contexts. Table 1 presents a summary of previous literature that explored the environmental impacts of COVID-19.

In this study, we propose a general hypothesis that there is a significant impact of COVID-19 pandemic on the environment in different contexts. To the best of our knowledge, there is a lack of information about the influence of

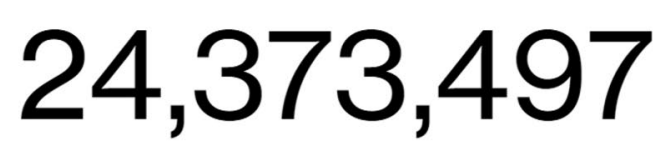

Confirmed cases worldwide

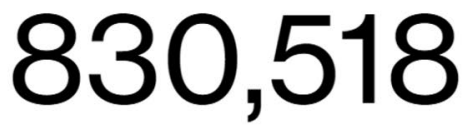

Deaths worldwide

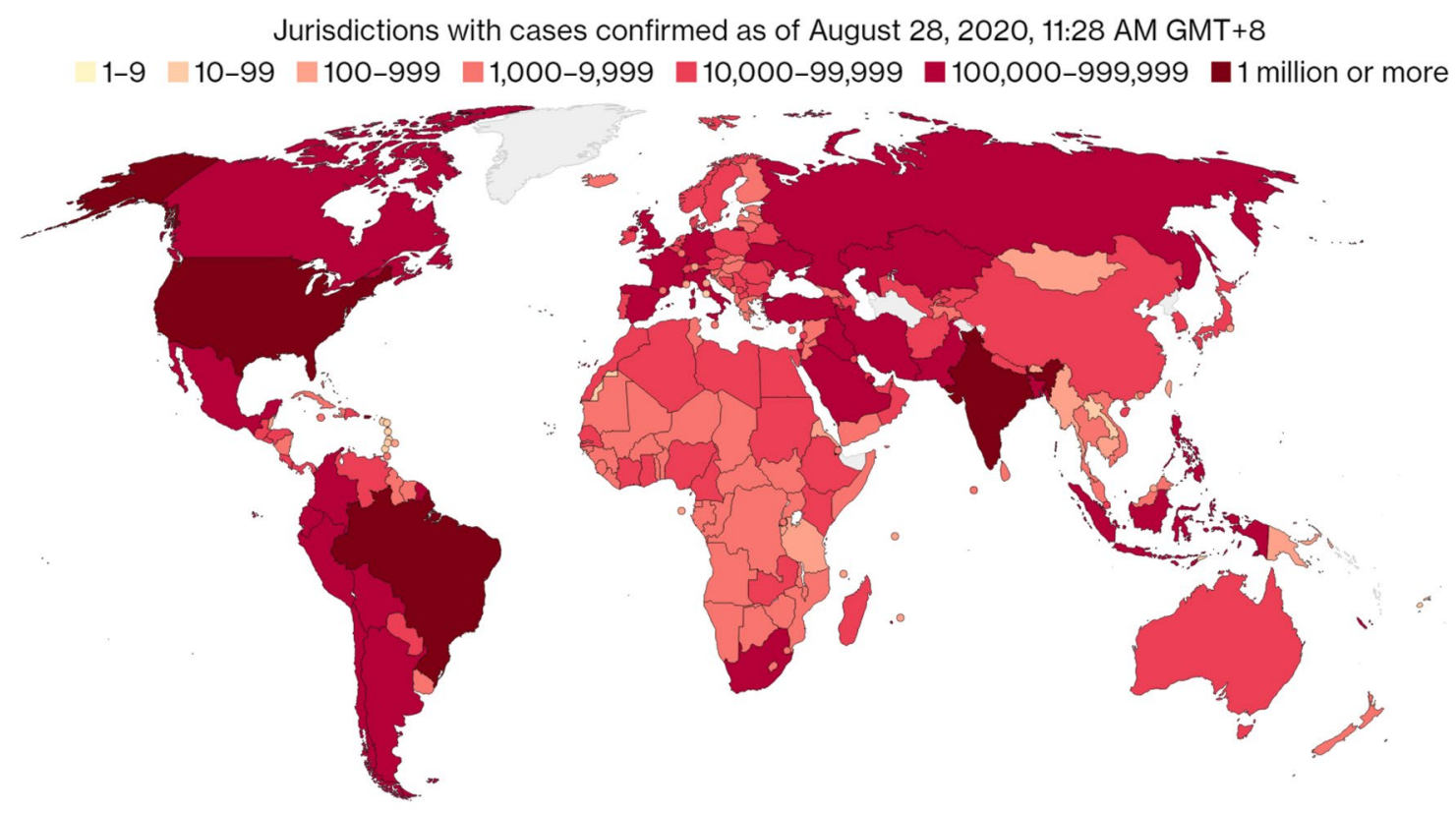

Fig. 1 COVID-19 pandemic, global confirmed and death cases 
Table 1 Summary of previous literature considering the environmental impact of COVID-19

\begin{tabular}{|c|c|c|c|}
\hline References & Context of the study & Country & Aim of the study \\
\hline Yu et al. (2020) & Medical waste & China & $\begin{array}{l}\text { Design a model for the management of medi- } \\
\text { cal waste }\end{array}$ \\
\hline Paital (2020) & The impact of COVID-19 on the nature & NA & Review the impact of COVID-19 \\
\hline Lokhandwala and Gautam (2020) & The impact of COVID-19 on air and water & India & $\begin{array}{l}\text { Analyze the impact of COVID-19 on the } \\
\text { quality of water surfaces and air during the } \\
\text { lockdown }\end{array}$ \\
\hline Lal et al. (2020) & $\begin{array}{l}\text { The impact of COVID-19 on the global } \\
\text { environment }\end{array}$ & NA & $\begin{array}{l}\text { Evaluate the influence of COVID-19 on the } \\
\text { global environment }\end{array}$ \\
\hline Tahir and Batool (2020) & $\begin{array}{l}\text { The impact of COVID-19 on the global } \\
\text { environment }\end{array}$ & NA & $\begin{array}{l}\text { Discuss the impact of COVID-19 on the } \\
\text { environment }\end{array}$ \\
\hline El Zowalaty and Järhult (2020) & Future lessons of COVID-19 & NA & $\begin{array}{l}\text { Discusses the future directions to maintain the } \\
\text { positive environmental influence }\end{array}$ \\
\hline López-Feldman et al. (2020) & $\begin{array}{l}\text { The impact of COIVID-19 on the environ- } \\
\text { ment }\end{array}$ & Latin America & $\begin{array}{l}\text { Discuss the impact of COVID-19 on regula- } \\
\text { tions and policymaking }\end{array}$ \\
\hline Mahmood et al. (2020) & $\begin{array}{l}\text { The impact of COIVID-19 on the environ- } \\
\text { ment }\end{array}$ & NA & $\begin{array}{l}\text { Discuss the impact of hand sanitizers on the } \\
\text { environment and people health }\end{array}$ \\
\hline Ghosh et al. (2020) & $\begin{array}{l}\text { The impact of COVID-19 on the environ- } \\
\text { ment }\end{array}$ & India & $\begin{array}{l}\text { Assess the impact of COVID-19 on the envi- } \\
\text { ronment using a developed quality index }\end{array}$ \\
\hline Chakraborty and Maity (2020) & $\begin{array}{l}\text { The impact of COVID-19 on the environ- } \\
\text { ment }\end{array}$ & NA & $\begin{array}{l}\text { Discuss the influence of COVID- } 19 \text { on com- } \\
\text { munity and worldwide environment, and the } \\
\text { potential methods in which the crisis can be } \\
\text { monitored }\end{array}$ \\
\hline
\end{tabular}

NA, not applicable

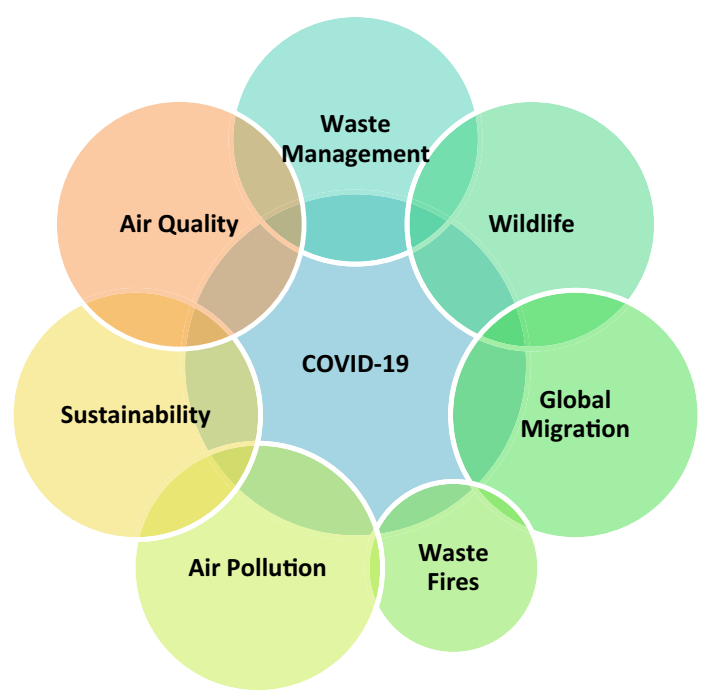

Fig. 2 Coronavirus pandemic (COVID-19) and its environmental impacts

COVID-19 pandemic on environmental factors. Hence, there is a room for further investigation of the potential impacts of the COVID-19 on the environment and its influence on human and living organisms from different aspects. Therefore, this study aims to investigate the environmental impacts that are linked to the COVID-19 pandemic.
This review outlines the COVID-19 impact on air quality improvements and health benefits, and the effects posing to the wildlife species. It also discusses the COVID-19 crisis through economic and migration lens. An overview of health care waste management and the emerging need to overcome undesired waste generation are elaborated. Together this paper provides a general knowledge of the factors affecting environmental sustainability during this period. As a result, this paper can help decision-makers to well notify the challenges and urgently asset new regulations towards a sustainable environment. Figure 2 presents the environmental impacts of COVID-19, which will be discussed in this study.

\section{COVID-19, air quality improvements and health benefits}

Carbon dioxide $\left(\mathrm{CO}_{2}\right)$ emissions are leading to a change in the worldwide climate (Nilashi et al. 2019; Yadegaridehkordi et al. 2020; Zhang and Zhang 2018). The increasing global temperature has reached high levels that cannot be neglected easily. The rise of the temperature and global warming has been indicated by greenhouse gas emissions (GHGs) (Requia et al. 2018; Sherafatian-Jahromi et al. 2016). There is a dynamic linkage between GHGs and air pollution, which is associated directly with negative impacts on human health. Regarding the Annual State of the Global Air Report, 95\% of the earth's citizens are breathing polluted 
Fig. 3 Deaths due to the Air Pollution in 2017 (Health Effects Institute State of Global Air, 2019)

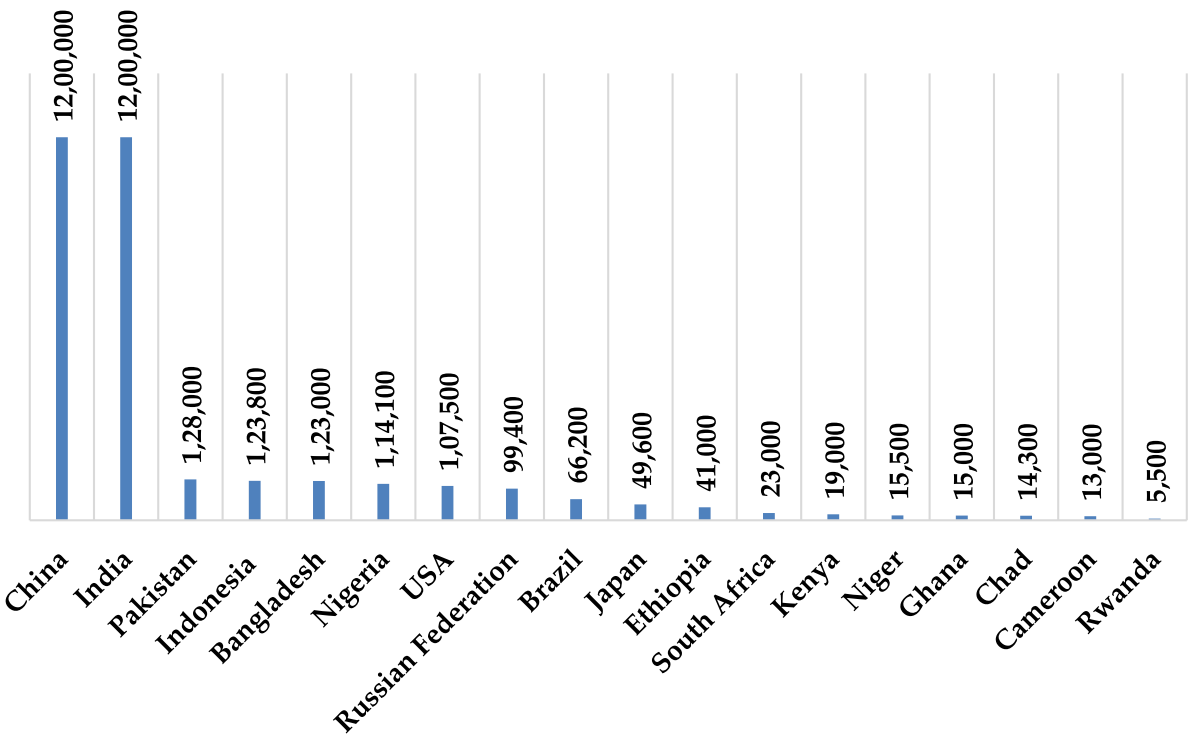

air, referring to the existing report by the Health Effects Institute (HEI) (2019). Figure 3 presents the total number of deaths due to the air pollution in 2017, as announced by Health Effects Institute State of Global Air (2019).

Although the COVID-19 crisis has resulted in widespread human suffering throughout the world, the level of air pollution is falling as a result of proceeding actions to combat the virus, indicating what is possible to achieve if we shift towards clean energy. If all constraints are removed, policymakers can proceed with green grids and transport system policies to achieve low rates of air pollution throughout the world. The risk of COVID-19 has highly threatened patients suffering from chronic obstructive pulmonary disease, cardiovascular, or high blood pressure diseases that were associated with long-term exposure to PM 2,5 (Tian et al. 2020). It is found that there is a direct relationship between the risk of getting complications if infected with COVID-19 and long-term exposure to air pollution. The results of a study by Tian et al. (2020) demonstrated the value of improving air quality in terms of health benefits and mildness of symptoms if infected. Additionally, Ogen (2020) found that the level of nitrogen dioxide contributes to the fatality of COVID-19. The associations between air pollution and COVID-19 in England have been also identified by Travaglio et al. (2020). They examined the relationship between the main air pollutants caused by burning fossil fuels and the death rates from SARS-CoV-2 in England. They compared up to date SARS-CoV-2 cases and public database mortality measurements with air quality data tracked at more than 120 sites across different areas. The authors found that the mortality of COVID-19 in various English regions is associated with the levels of certain markers with poor air quality, ozone, and nitrogen oxides. Further, Conticini et al. (2020) investigated the impact of atmospheric pollution on SARS-CoV-2 lethality in Northern Italy and found that a high level of pollution in a region is a co-factor of the recorded high degree of lethality in this area.

\section{COVID-19 and its impact on air pollution}

During the COVID-19 crisis, the lockdown has impacted the natural environment positively to a certain level (Muhammad et al. 2020). COVID-19 lockdown has led to an improvement in air quality associated with an overall drop in carbon emissions and decreased water pollution in several cities around the world (Saadat et al. 2020). According to Myllyvirta (2020a), approximately $40 \%$ reduction in average levels of nitric dioxide pollution $\left(\mathrm{NO}_{2}\right)$ has been achieved with coronavirus-fighting measures recently, and an average of $10 \%$ reduction in pollution of particulate matter has resulted in a reduction of 11.000 deaths caused by air pollution (95\% confidence: 7.000 to 
$21,000)$. This impact is due to a 37 percent decrease in coal production and an estimated $1 / 3$ reduction in oil consumption (Myllyvirta 2020a). Oil and coal are the most $\mathrm{NO}_{2}$ polluting sources and the most important sources of pollution of particulate matter throughout Europe. Portugal, Norway, France, Croatia, Spain, Italy, and Finland comprise the greatest reduction in $\mathrm{NO}_{2}$ pollution levels (Myllyvirta 2020a). The biggest reductions in particulate matter pollution have been reported in Greece, Portugal, Finland, Norway, Poland, Sweden, and Spain (Myllyvirta 2020a).

Data from EEA Member countries indicate that in many European cities, where lockdown measures have been introduced, the concentrations of $\mathrm{NO}_{2}$ have been decreased, as these pollutants often released by road transport. While a decrease in fine particulate matter concentration (PM2,5) can be expected, a steady decrease in fine particulate matter in European cities has not yet been seen. This can be explained by a wide range of its main sources, including fuel for residential/commercial/institutional buildings, industrial activities, and road transport at the European level. A significant fraction of the particulate matter in the atmosphere is also formed from other air pollutant reactions, including ammonia, a pollutant typically emitted at this time of year through the use of agricultural fertilizers. Other variables, such as environmental conditions, may also contribute significantly to a variation in pollution rates. Meteorological changes can also contribute to an increase in air emissions and, along with non-linear relationships between emission changes and concentration changes, explain the likelihood that lower air pollution will not occur at all locations.

$\mathrm{CO}_{2}$ emissions in 2020 show a vigorous decrease when measured against 2019, despite the seasonal differences. Early measures of emissions' variation, referring to the satellite observational evidence of atmospheric pollutants (Myllyvirta 2020b), have indicated that we may be viewing the hugest decline of emissions from the Second World War. Figure 4 presents the estimated $\mathrm{CO}_{2}$ emissions in February and March of 2020 in several selected countries when compared to 2019 (Liu et al. 2020). As Fig. 4 highlights, the US, EU 27 \& UK, India, Brazil, China, and Japan have experienced a huge decrease in $\mathrm{CO}_{2}$ emissions in March2020 compared to 2019.

\section{COVID-19 and healthcare waste management}

All waste generated by biomedical research institutions, health facilities, medical laboratories, and waste generated from scattered or minor sources are healthcare waste. Whilst hospitals generate a large volume of health waste, still, they produce a small proportion of waste among the total number of sources. The COVID-19 crisis has an increasing environmental impact linked to higher plastic consumption and further disposal, yet the increasing critical health problems have considerably magnified the existing threat. Part of the vivid environmental issues during this pandemic is the unexpected
Fig. $4 \mathrm{CO}_{2}$ emissions in 2020 compared to 2019 (Liu et al., 2020)

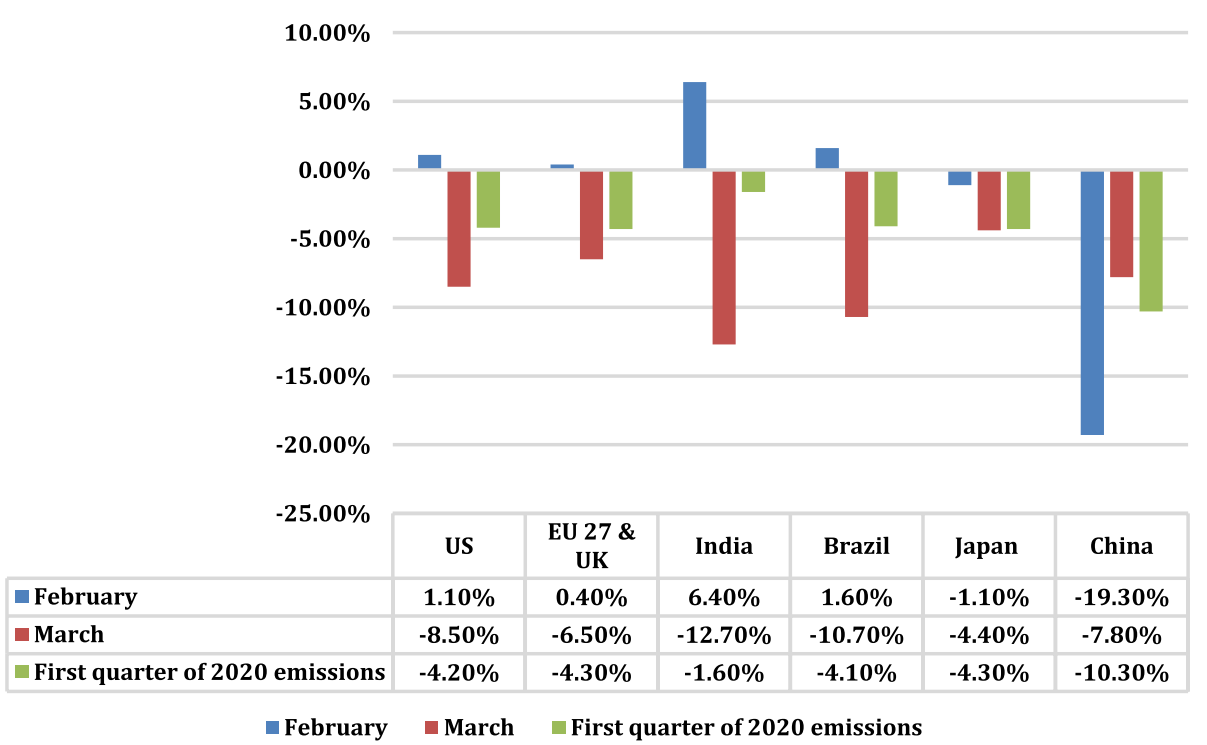


rise of plastic item demands in terms of healthcare usage to protect the overall community, affected people, medical and service employees (Klemeš et al. 2020). The broad usage of safety equipment around the globe has developed enormous crucial supply chain interruptions and waste processing issues. The emerging need direction is anticipated to meet the universal crisis curve because of the increasing need for several plastic items, such as individual safety appliances, gloves and masks for medical employees, disposable plastic items for life-support tools, respirators, and common plastic items involving medical needles. In the medical sector, used plastic items are usually polluted by pathogens, and should be managed as hazardous disposals. Even before the beginning of the COVID-19 crisis, the processing of plastic disposals was regarded as a critical environment-related matter because of the increasing challenges of potential contamination in the earth and ocean ecosystem (Rajmohan et al. 2019). Universal disposal processing procedures are still incapable to regulate adequately with current plastic disposals, the forthcoming wave in the volume of disposals during the COVID-19 crisis warns to surpass current disposal processing procedures as well as medical organizations' potentials (Schlegel 2020; Yu et al. 2020). Healthcare disposals from several healthcare centers are extremely complex owing to the demand to demolish any remaining pathogens (Windfeld and Brooks 2015). Inappropriate treatment of medical waste poses serious hazardous transmission of secondary diseases as a result of the exposure to infectious

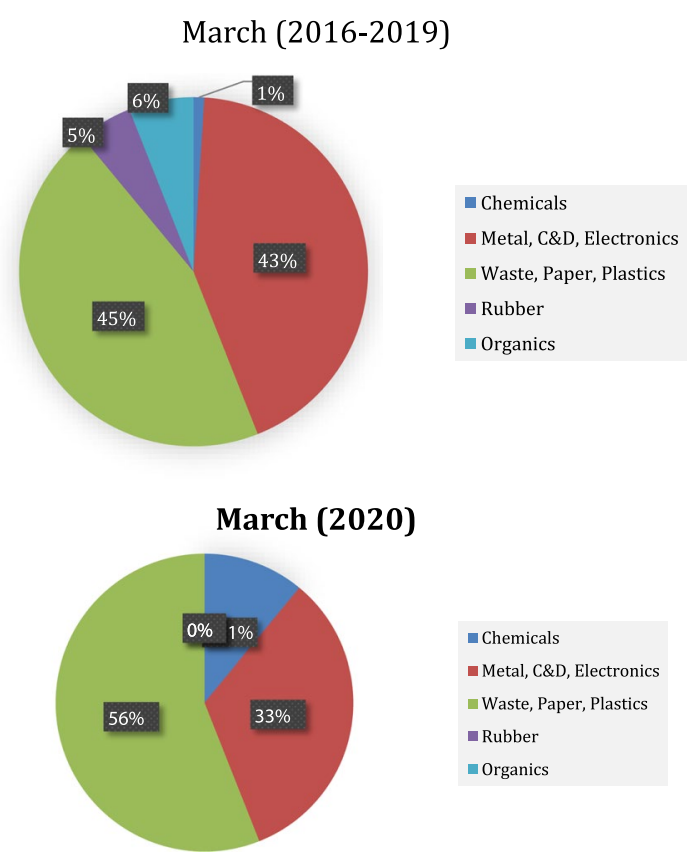

Fig. 5 COVID-19's effect on waste and recycling fires in US/CAN (Fogelman, 2020) agents by health workers, waste pickers, waste-cite workers, patients, and the general public, where waste is disposed of.

In assessing health-related waste management, it is useful to utilize a standard ground for measurement, so that indicators from various areas can be cross-checked (Windfeld and Brooks 2015). The optimum method to monitor the influence of healthcare-related disposals is to create less contaminated waste. One of the best powerful approaches to achieve this is to assure that only contagious healthcare disposals are forwarded for special processing, and the other safe healthcare disposals should be manipulated in the same procedure as domestic disposals. This might be achieved by educating medical staff as well as the deployment of uniform healthcare waste flows (Meleko et al. 2018) and wastebasket colors.

\section{COVID-19 and waste fires}

The impact of COVID-19 on the growing amount of waste was confirmed, on the health care community particularly, and the increasing amount of domestic waste during the lockdown in general (You et al. 2020). The rise in domestic waste amount during the quarantine has raised environmental professionals' worries regarding waste fires (United States Environmental Protection Agency 2020).

The impact of COVID-19 on waste fires was indicated in the report by Fogelman (Fogelman 2020). As Fig. 5 presents, waste fires constitute 56\% of the total fires in March 2020 , compared to $45 \%$ in the previous four years. Fogelman (2020) linked this increase to the quarantine regulations, which influenced people's traditional and online shopping dramatically and led to an increased amount of waste that people couldn't handle properly. A new survey was launched to examine consumer behavior during the COVID-19 in the USA and indicated consumers' intention to increase their online purchase more than usual during the coming holiday (Modern Materials Handling 2020).

\section{COVID-19 impact on wildlife}

COVID-19 crisis has stopped people's activities; it gives wildlife an emerging release to get out of its allocated habitats. In people-dominated areas wildlife activities are restricted and banned. Wildlife Institute of India, published a new data through a platform "Lockdown Wildlife Tracker" to show easy wildlife movement in people reigned areas (Paital 2020). This platform enables volunteers to document wildlife actions, the collected data then can be available to the research community to use and investigate. Many reports have spotted a movement of wild animals in people-dominated areas: coyotes and dears are seen in the USA, wild boars are spotted in Italy, peacocks are rooming in Bangor, 
goats are moving in Wales, and beautiful insects take the chance to discover the plants in the UK (Loring 2020).

It is expected that vehicle movements will be reduced dramatically this year, which will decrease the number of wildlife species killed on the streets (Shilling and Waetjen 2020). In the short-run time of quarantine, animal movements have been impacted rapidly, comparing to previous years, in which people-dominated actions have resulted in catastrophic results on fauna and flora of the earth. This short-term change in human behaviors raises the demand for reducing the consumption of natural resources. This highlights how the earth can restore its wellness without people disturbance. Thus, firm environmental regulations need to be implemented after COVID-19 to foster the earth recovery.

Additionally, possible grounds characterized by the declined financial capacity in pandemic regions, in which less financial support will be provided to protect endangered animals and habitats (Loring 2020). The documentation of animals roaming highlighted the positive result of COVID19; still, this is a delusional view, as animals that are in major threat of eradication require consistent demand for people interference to stay alive. Unfortunately, these spices are now being abandoned without care. An example of that, the advantages of broad ecotourism marketing in Africa, as it presents a vital effort towards the protection of protected areas near Mount Kilimanjaro (Hakovirta and Denuwara 2020). Since most people's actions, which might be considered as a detriment to nature, in fact, present no-damaging influence, and can provide supplies for certain living species.

Coronavirus crisis was started in the seafood market in Wuhan-China. The COVID-19 has raised people's awareness of the threat of new communicable diseases that are transferred from animals. Even though it is still unsure that wildlife could transfer the COVID-19 virus, many studies suggested that pangolins, bats, or snakes can be a possible carrier of the virus (Eslami and Jalili 2020; Kumar et al. 2020). As indicated by Chakraborty and Maity (2020), $60 \%$ of such viral diseases are originated in animals and $70 \%$ of these are passed to people from wild animals. The experience proofed that many emerging diseases were transformed from wild animals to people (Can et al. 2019). This happened with Ebola, HIV, SARS, AIDS, Ebola, and now COVID-19. Hence, the wildlife markets might strengthen the threats of new diseases. Many researchers have encouraged governments to forbid the wildlife trade forever. These rules, if followed, would aid to preserve people's health from any upcoming crisis like COVID-19. Many governments are adopting rigid efforts to forbid wildlife business in the raise of COVID-19 (Pagani-Núñez 2020). As a result, China has forced restrictions on wildlife trade, particularly animals like bats, wolfs, pangolins and civets. Although China has restricted wildlife businesses nationwide, many ecologists desire that the universal pandemic will drive China to involve more in the defense of biodiversity. They also demand that many regions will restrict wildlife markets in response to the COVID-19.

\section{COVID-19 and global migration}

The effects of migration on $\mathrm{CO}_{2}$ emissions have been proven in the previous research (Komatsu et al. 2013). It has been shown that the effect of urban-to-urban migration on energy consumption is not significant, while rural-to-urban migration can negatively impact the $\mathrm{CO}_{2}$ emissions (Komatsu et al. 2013). Besides, direct energy consumption can produce emissions through the rural-to-urban migrants $(\mathrm{Ru}$ et al. 2015). Immediately after arrival to the city, migrants moved up the energy ladder to replace biomass fuels with electricity, coal, and liquefied oil gas (Ru et al. 2015). The energy mix of rural-to-urban migrants differs from that of long-term urban residents. When transferring from biomass to coal, non-neutral $\mathrm{CO}_{2}$ emissions by the migrants are 2,4 times higher than in rural areas and 14 percent higher than in urban areas. Migration also increases $\mathrm{SO}_{2}$ and mercury emissions, however, these emissions decrease significantly in incomplete combustion products, including particulate matter. All of these developments have substantial effects on health, climate, and air quality, taking into account the scale of urbanization (Ru et al. 2015).

Global migration has raised an important issue during the COVID-19 outbreak related to environmental concerns. The impact is becoming apparent almost three months after the COVID-19 outbreak as the pandemic reshaped the international migration governance and forced displacement. Concerning the banned international travels, the health of international migrant workers must be considered during the COVID-19 epidemic. Out of 150 million global international migrant workers (IMWs), $95 \%$ live in five WHO regions, in which COVID-19 cases were confirmed (Liem et al. 2020). The lack of a systematic response to IMW reveals a major weakness in public health planning. IMWs encounter more access barriers (e.g., inadequate health insurance) to health care in host countries, particularly migrants' domestic workers, in relation to the international migrants (e.g., international students) (Hall et al. 2018; Liem et al. 2020). The burden of IMWs is high for specific mental disorders (e.g., 
depression) and the quality of life for them is lower than local populations under normal circumstances (Liem et al. 2020). Due to the COVID-19 epidemic, this situation could get worse by the fear of the quarantine imposed by the government and income loss (Hall et al. 2018; Hargreaves et al. 2019; Liem et al. 2020).

Migrants, especially in low-paid jobs, may suffer seriously as they are highly vulnerable to COVID-19 spread in countries that have already been affected and those in which the pandemic is expanding (Guadagno 2020). Statics show that migration increases in the countries, specifically developing countries, due to several structural factors such as weak rule of law and inadequate health system organization. Hence, irregular mobility of such migrants across the boarders increases the vulnerability of transmitting the disease via direct contact with other migrants. Overall, migrants play a major role in responding to COVID-19 through working in critically affected areas. Moreover, migrating across borders without documentation or regular health checks puts anyone on their extended path at grave risk of COVID-19.

Gulf Cooperation Council (GCC) states are a significant place for workers from South Asia. If we consider Saudi Arabia as a case study, low qualified workforce migrants in packed residences have been extremely impacted by the COVID-19. The migrant workforce constitutes 38\% of the community in Saudi Arabia. The total number of migrants in Saudi Arabia in the mid-year of 2019 was around 13.1 million (UN DESA 2019). The Ministry of Health has presented an official report about the migrant workers infected by the virus, which demonstrates the distinction risk of the pandemic on the migrant workforce. According to the Saudi Ministry of Health (2020), until May 2020, 75\% of all infected people in Saudi Arabia were migrant workers. Besides, as several global migrant workforces in the GCC countries went back to their countries or locked down due to the travel restrictions, they were unable to send funding to their dependents. The economic impact of the quarantine rules has influenced their income significantly. Consequently, this has an impact on the oil price around the globe. Ratha et al. (2020) reported that the oil price has fallen around the globe causing a large decrease in cash transfer to South Asia by $22 \%$.

\section{COVID-19 and sustainability}

The crisis we are addressing has not only impacted the physical care of millions of citizens, but also has a significant impact on sustainability, which has been addressed in many studies (Hakovirta and Denuwara 2020; Klemeš et al. 2020). Sustainability addresses three aspects of economics, society, and the environment. Combined with the fast spread of COVID-19, the economic outcomes have dropped severely, social problems like family violence have expanded, and many animal species have suffered from the lack of protection forces by conservationists who are locked in their homes (Hakovirta \& Denuwara 2020). First, the global economic aspect has been impacted devastatingly, as more and more people lose their financial savings, especially people who earn their income day-to-day. Additionally, employers have adopted difficult strategies during the pandemic, as they face losing their businesses. Many workers lost their jobs during the crisis, as their employers couldn't pay their salaries. Broad industries such as airlines, tourism, and transportation, who have faced invincible outcomes, have sought for the government aid. The crisis has also developed more force on organizations to balance the effectiveness and expense/ gains of the international supply chain process facing the performance of the local supply chain. Converting to the local supply chain can lower the reliance on a broadly shattered international supply system (Hakovirta and Denuwara 2020). Although this shift is anticipated to better supply of citizens' needs, it might raise the production costs.

Second, the economic aspect raises the influence of the crisis on societies. Many people have suffered from losing their jobs and family support, as they couldn't utilize a suitable environment to distance work. People who don't have sufficient skills to work from home may shift to product delivery or similar jobs, which will put them in great danger of being infected. Besides, the economic discrimination gap has a reverse impact on the political force. People who suffer from the economic inequality gap feel more distressed, which can increase people feelings of social disconnect (Pazzanese 2016). Therefore, these outcomes have raised people's sense of the crisis and have impacted their mental health.

Lastly, the influence of the pandemic on environmental sustainability, which is reflected by the stunning environment healing during the crisis. It is anticipated that such a change in the global nature, in a short time, would not be possible without the pandemic and its consequences (Paital 2020). Attention must be paid to develop efficient strategies to boost global nature. Open issues must be revised, analyzed, and managed by governments to adopt the suitable approaches for nature recovery as well as retaining the economical development.

\section{COVID-19 and environmental transmission}

There is no confirmed data available about the transmission of COVID-19 through person-to-person, breathing, 


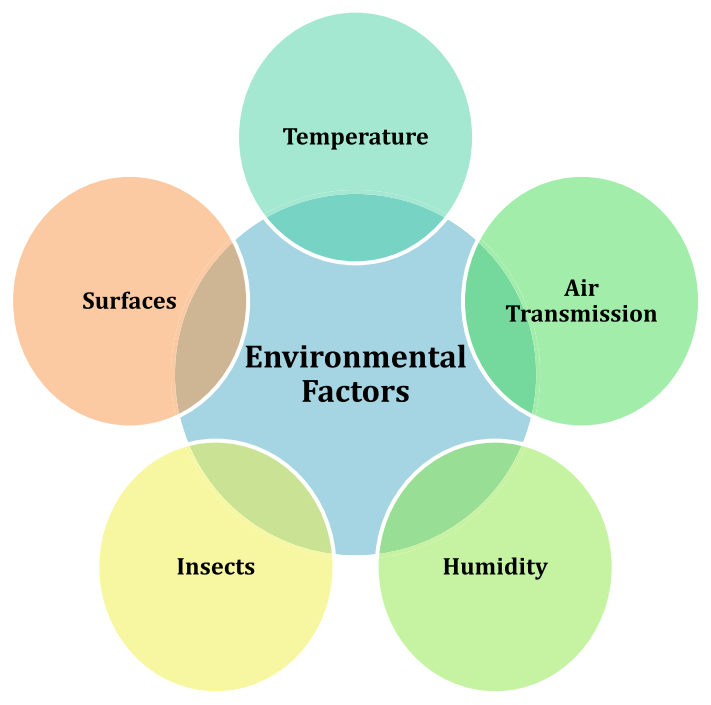

Fig. 6 Environmental variables related to COVID-19

eating, or drinking, and neither any data available regarding the existence of the virus in domestic wastes (Eslami and Jalili 2020). Various variables can be engaged in transferring COVID-19. A few variables can be tied to the surrounding environment and people's actions. The movement of people, migration, social contact, weather changes, agricultural expansion, and interaction with household animals and wildlife are linked to the disease transmission (Barratt et al. 2019; Dehghani and Kassiri 2020). Additionally, the effects of surrounding environmental variables such as the surrounding climate, linked to the virus, have not been broadly explored. The process in which the virus could penetrate the human body and causes the infection is still under investigation (World Health Organization 2020a).

Among the environmental variables, increasing the temperature during the summertime can impact the outrage of COVID-19 and it has gained scientists' interests (Abbasi et al. 2020; Wang et al. 2020). Mandal and Panwar (2020) have linked higher rates of COVID-19 infection to colder countries. Interestingly, Wang et al (2020) reported that with the $1{ }^{\circ} \mathrm{C}$ rise of air temperature, the cumulative number of infected people drops by $0.86 \%$. Another research by Chin et al. (2020) declared the resistance of the virus at $4{ }^{\circ} \mathrm{C}$ for a long period, while at $70{ }^{\circ} \mathrm{C}$, its survival lasts for only $5 \mathrm{~min}$. Moreover, Chin et al. (2020) stated that the virus could stay stable at various $\mathrm{pH}$ measures that range from 3-10, at indoor temperature. On the other hand, Eslami and Jalili (2020) indicated the insignificant link between the COVID-19 infected cases and environmental factors such as humidity and wind speed. Overall, $\mathrm{pH}$, sunlight, and high temperature can help in defeating the virus (World Health Organization 2020b). Although insufficient proofs are available of COVID-19 transmission by arthropod-borne insects, few researchers have indicated that insects such as beetles are the main transporters of germs, by flying over and contacting contaminated areas. Additionally, inadequate information is available about the transmission of COVID-19 virus through the air within a minimum range of 6 feet, via liquid surfaces, or food (Eslami and Jalili 2020). Figure 6 presents a diagram about the key environmental variables related to COVID-19.

\section{Conclusion}

This research supplements previous researches on environmental impacts during extreme health events (Lin et al. 2006; Qiu et al. 2018). The COVID-19 pandemic in 2020 is one of the recent severe crises and worldwide urgent health situations (Wang and Su 2020). The exploration of the impact of the crisis on the environment during the crisis can not only present a ground for other researchers to evaluate the influence of the crisis on the environment, but also can support the theoretical studies of the connection between health-related crisis and the environment through considering an emergency-environment aspect. Research findings can be summarized as follows:

- The whole globe involving 210 countries are applying quarantine with various degrees of strictness to face COVID-19. India and China had been applying strict and quick restrictions to effectively manage the infection and decrease the death average from COVID-19. Therefore, $\mathrm{NO}_{2}$ and $\mathrm{CO}_{2}$ pollution is dramatically declined in many cities across the globe (Paital 2020). The reduction in air and water pollution was noticeably recognized in many regions like France, Italy, Los Angeles, Spain, and Wuhan city of China. Because of the clean air, clear water, and the free movement of wild animals, humans started to sense the environment recovery. There are noticeable health advantages of air pollution drop, which entail health protection through and after the pandemic (Shrestha et al. 2020). The significance of proceeding the current advantages, through air pollution reduction rules, to save people should be maintained.

- The desirable outcome on nature has influenced wild animals to overcome human-dominated areas' restrictions. As the lockdown forces a broad stop of public and private 
means of transportation, animals are experiencing noisefree areas in people-dominated zones. It is like that the globe is restoring its wellness rapidly. People started to realize that modern life can be carried on without harming the environment dramatically. It is a glance of what the globe might be like without fossil energy sources and the hope that people could survive from this pandemic into a healthier, cleaner globe. This can happen if a long-lasting mindset adopted from several institutions, social communities, and individual attitudes, followed by restricted regulations and policies to stop environmental deterioration. Post-COVID-19 can slow down people dominancy and environmental damage. Hence, the self-refreshed environment, without people interference effort, can become permanent with human awareness of the post-COVID-19 times.

- The health waste production grows rapidly during the crisis which positions a vital threat to both health workers and the public, if gathered or managed inappropriately (Yu et al. 2020). Therefore, appropriate planning and management of the significantly growing health waste and its threat in the time of the crisis is of great importance. On the other hand, the management of the domestic waste during the pandemic has also raised potential environmental threats.

- Researches have indicated that minimizing the incidence of touching areas by direct hands and sanitizing surrounding areas can minimize the amount of the virus load on areas and the number of infected people (Eslami and Jalili 2020). The main significant answer to this health crisis so far is to sanitize areas. It is not yet clear if any other ways can transmit the virus and the impact of the surrounding areas on the spread of the virus.

Finally, the COVID-19 crisis is an international health disaster with serious impacts on health and business. Still, COVID-19 can enhance the air quality by reducing carbon emissions which will lead to enhanced environmental health. It is not clear yet to what extent the favorable influences will remain, as soon as the travel restrictions are released (El Zowalaty and Järhult 2020), but the impact of COVID-19 will increase people awareness of the environmental issues. This impact will rely on the efficiency and strictness of global health rules and the revive of business and market actions all over the globe. Future work can address future directions for policymakers on how to benefit from people awareness regarding the environment to maintain a favorable influence.

\section{Compliance with ethical standards}

Conflict of interest The authors declare that they have no conflict of interest.

\section{References}

Abbasi F, Samaei MR, Manoochehri Z, Jalili M, Yazdani E (2020) The effect of incubation temperature and growth media on index microbial fungi of indoor air in a hospital building in Shiraz, Iran. J Build Eng 31:101294

Annual State of the Global Air Report (2019) How clean is your air? https://www.stateofglobalair.org/air

Barratt R, Shaban RZ, Gilbert GL (2019) Clinician perceptions of respiratory infection risk; a rationale for research into mask use in routine practice. Infection Disease Health 24(3):169-176

Can ÖE, D'Cruze N, Macdonald DW (2019) Dealing in deadly pathogens: taking stock of the legal trade in live wildlife and potential risks to human health. Global Ecol Conserv 17:e00515

Chakraborty, I., \& Maity, P. (2020). COVID-19 outbreak: migration, effects on society, global environment and prevention. Sci Total Environ 138882.

Chin A, Chu J, Perera M, Hui K Yen H-L, Chan M, Peiris M, Poon L (2020) Stability of SARS-CoV-2 in different environmental conditions. medRxiv

Conticini E, Frediani B, Caro D (2020) Can atmospheric pollution be considered a co-factor in extremely high level of SARS-CoV-2 lethality in Northern Italy? Environ Pollut 114465.

Dehghani R, Kassiri H (2020) A brief review on the possible role of houseflies and cockroaches in the mechanical transmission of coronavirus disease 2019 (COVID-19). Archives of Clinical Infectious Diseases, 15 (COVID-19).

[Record \#6273 is using a reference type undefined in this output style.]

El Zowalaty ME, Järhult JD (2020) From SARS to COVID-19: a previously unknown SARS-CoV-2 virus of pandemic potential infecting humans-Call for a One Health approach. One Health 9:100124

Eslami H, Jalili M (2020) The role of environmental factors to transmission of SARS-CoV-2 (COVID-19). AMB Express 10(1):1-8

Fogelman R (2020) March 2020 fire report: COVID-19's effect on waste, recycling facility fires. https://www.waste $360 . \mathrm{com} / \mathrm{safet}$ y/march-2020-fire-report-covid-19s-effect-waste-recycling-facil ity-fires

Ghosh S, Das A, Hembram TK, Saha S, Pradhan B, Alamri AM (2020) Impact of COVID-19 induced lockdown on environmental quality in four indian megacities using landsat 8 OLI and TIRS-Derived data and mamdani fuzzy logic modelling approach. Sustainability 12(13):5464

[Record \#6351 is using a reference type undefined in this output style.] [Record \#6034 is using a reference type undefined in this output style.]

Hall BJ, Shi W, Garabiles MR, Chan EW (2018) Correlates of expected eMental Health intervention uptake among Filipino domestic workers in China. Global Mental Health 5

Hargreaves S, Rustage K, Nellums LB, McAlpine A, Pocock N, Devakumar D, Aldridge RW, Abubakar I, Kristensen KL, Himmels JW (2019) Occupational health outcomes among international migrant workers: a systematic review and meta-analysis. Lancet Global Health 7(7):e872-e882

Health Effects Institute State of Global Air (2019) State of global air.

Kanniah KD, Zaman NAFK, Kaskaoutis DG, Latif MT (2020) COVID-19's impact on the atmospheric environment in the Southeast Asia region. Sci Total Environ 139658.

Kavanagh MM (2020) Authoritarianism, outbreaks, and information politics. Lancet Public Health 5(3):e135-e136

Klemeš JJ, Van Fan Y, Tan RR, Jiang P (2020) Minimising the present and future plastic waste, energy and environmental footprints related to COVID-19. Renew Sustain Energy Rev 127:109883

Komatsu S, Ha HD, Kaneko S (2013) The effects of internal migration on residential energy consumption and $\mathrm{CO} 2$ emissions: A case study in Hanoi. Energy Sustain Dev 17(6):572-580 
Kumar V, Pruthvishree B, Pande T, Sinha D, Singh B, Dhama K, Malik YS (2020). SARS-CoV-2 (COVID-19): zoonotic origin and susceptibility of domestic and wild animals. J Pure Appl Microbiol

Lal P, Kumar A, Kumar S, Kumari S, Saikia P, Dayanandan A, Adhikari D, Khan M (2020) The dark cloud with a silver lining: assessing the impact of the SARS COVID-19 pandemic on the global environment. Sci Total Environ 139297.

Liem A, Wang C, Wariyanti Y, Latkin CA, Hall BJ (2020) The neglected health of international migrant workers in the COVID19 epidemic. Lancet Psychiatry 7(4):e20

Lin K, Fong DY-T, Zhu B, Karlberg J (2006) Environmental factors on the SARS epidemic: air temperature, passage of time and multiplicative effect of hospital infection. Epidemiol Infect 134(2):223-230

Liu Z, Deng Z, Ciais P, Lei R, Feng S, Davis SJ, Wang Y, Yue X, Lei Y, Zhou $\mathrm{H}$ (2020) Decreases in global $\mathrm{CO}_{2}$ emissions due to COVID19 pandemic. arXiv preprint arXiv:2004.13614

Lokhandwala S, Gautam P (2020). Indirect impact of COVID-19 on environment: a brief study in Indian context. Environ Res 109807.

Loring K (2020) In San Francisco, coyotes are your wildest neighbors. Retrieved 19-5-2020 from https://www.kalw.org/post/sanfrancisco-coyotes-are-your-wildest-neighbors\#stream/0

López-Feldman A, Chávez C, Vélez MA, Bejarano H, Chimeli AB, Féres J, Robalino J, Salcedo R, Viteri C (2020) Environmental impacts and policy responses to Covid-19: a view from Latin America. Environ Resource Econ 1-6.

Mahmood A, Eqan M, Pervez S, Tabinda AB, Yasar A, Brindhadevi K, Pugazhendhi A (2020) COVID-19 and frequent use of hand sanitizers; human health and environmental hazards by exposure pathways. Sci Total Environ 140561.

Mandal CC, Panwar M (2020) Can the summer temperatures reduce COVID-19 cases? Public health 185:72-79

Meleko A, Tesfaye T, Henok A (2018) Assessment of healthcare waste generation rate and its management system in health centers of bench Maji zone. Ethiopian J Health Sci 28(2):125-134

Modern Materials Handling (2020) Voxware reports on COVID-19's impact on consumer holiday shopping behavior. Retrieved 25-July from https://www.mmh.com/article/voxware_surve y_finds_covid_19s_impact_on_holiday_shopping_behav iors_will_st

Muhammad S, Long X, Salman M (2020) COVID-19 pandemic and environmental pollution: a blessing in disguise? Sci Total Environ 138820.

Myllyvirta L (2020a) 11,000 air pollution-related deaths avoided in Europe as coal, oil consumption plummet. https://energyandcleana ir.org/air-pollution-deaths-avoided-in-europe-as-coal-oil-plumm et/

Myllyvirta L (2020b) Coronavirus temporarily reduced China's CO2 emissions by a quarter. Carbon Brief https://www.carbonbrief.org/ analysis-coronavirus-has-temporarily-reduced-chinas-co2-emiss ions-by-a-quarter

Nilashi M, Asadi S, Abumalloh RA, Samad S, Ibrahim O (2020) Intelligent recommender systems in the COVID-19 outbreak: the case of wearable healthcare devices. J Soft Comput Decision Support Syst 7(4):8-12

Nilashi M, Rupani PF, Rupani MM, Kamyab H, Shao W, Ahmadi H, Rashid TA, Aljojo N (2019) Measuring sustainability through ecological sustainability and human sustainability: a machine learning approach. J Clean Prod 240:118162
Ogen Y (2020) Assessing nitrogen dioxide (NO2) levels as a contributing factor to the coronavirus (COVID-19) fatality rate. Sci Total Environ 138605.

Pagani-Núñez E (2020) COVID-19: ban'orientalism'by critics of wildlife trade. Nature 579(7800):497-497

Paital B (2020) Nurture to nature via COVID-19, a self-regenerating environmental strategy of environment in global context. Sci Total Environ 139088.

Pazzanese C (2016) The costs of inequality: increasingly, it's the rich and the rest. Harvard Gazette.

Qiu W, Chu C, Mao A, Wu J (2018) The impacts on health, society, and economy of SARS and H7N9 outbreaks in China: a case comparison study. J Environ Public Health

Rajmohan KVS, Ramya C, Viswanathan MR, Varjani S (2019) Plastic pollutants: effective waste management for pollution control and abatement. Curr Opinion Environ Sci Health 12:72-84

Ratha DK, De S, Kim EJ, Plaza S, Seshan GK, Yameogo ND (2020) COVID-19 crisis through a migration lens

Requia WJ, Mohamed M, Higgins CD, Arain A, Ferguson M (2018) How clean are electric vehicles? Evidence-based review of the effects of electric mobility on air pollutants, greenhouse gas emissions and human health. Atmos Environ 185:64-77

Ru M, Tao S, Smith K, Shen G, Shen H, Huang Y, Chen H, Chen Y, Chen X, Liu J (2015) Direct energy consumption associated emissions by rural-to-urban migrants in Beijing. Environ Sci Technol 49(22):13708-13715

Saadat S, Rawtani D, Hussain CM (2020) Environmental perspective of COVID-19. Sci Total Environ 138870.

Saudi Ministry of Health (2020) Highlights of the press conference of the official spokesperson. Retrieved 7-May from https://twitt er.com/SaudiMOH/status/1258455943546900482

Schlegel I (2020) How the plastic industry is exploiting anxiety about COVID-19. Retrieved 18-April from www.greenpeace.org/usa/ how-the-plastic-industry-is-exploiting-anxiety-about-covid-19/

Sherafatian-Jahromi R, Othman MS, Law SH, Ismail NW (2016) Tourism and $\mathrm{CO} 2$ emissions nexus in Southeast Asia: new evidence from panel estimation. Environ Dev Sustain 19(4):1407-1423. https://doi.org/10.1007/s10668-016-9811-x

Shilling F, Waetjen D (2020) Special report: impact of COVID19 on California traffic accidents

Shrestha AM, Shrestha UB, Sharma R, Bhattarai S, Tran H, NT, Rupakheti M (2020) Lockdown caused by COVID-19 pandemic reduces air pollution in cities worldwide.

Tahir MB, Batool A (2020) COVID-19: healthy environmental impact for public safety and menaces oil market. Sci Total Environ 140054.

Tian H, Liu Y, Song H, Wu C-H, Li B, Kraemer MU, Zheng P, Yan X, Jia G, Zheng Y (2020) Risk of COVID-19 is associated with long-term exposure to air pollution. medRxiv.

Tobías A, Carnerero C, Reche C, Massagué J, Via M, Minguillón MC, Alastuey A, Querol X (2020) Changes in air quality during the lockdown in Barcelona (Spain) one month into the SARS-CoV-2 epidemic. Sci Total Environ 138540.

Travaglio M, Yu Y, Popovic R, Leal NS, Martins LM (2020) Links between air pollution and COVID-19 in England. medRxiv

UN DESA (2019) Retrieved 18-July from https://www.un.org/en/ development/desa/population/migration/data/estimates2/estim ates19.asp 
United States Environmental Protection Agency (2020) Recycling and sustainable management of food during the coronavirus (COVID19) public health emergency. Retrieved 24-July from https://www. epa.gov/coronavirus/recycling-and-sustainable-management -food-during-coronavirus-covid-19-public-health

Wang M, Jiang A, Gong L, Luo L, Guo W, Li C, Zheng J, Li C, Yang B, Zeng J (2020) Temperature significant change COVID-19 transmission in 429 cities. MedRxiv

Wang Q, Su M (2020) A preliminary assessment of the impact of COVID-19 on environment-a case study of China. Sci Total Environ 138915.

Wilder-Smith A, Freedman DO (2020) Isolation, quarantine, social distancing and community containment: pivotal role for old-style public health measures in the novel coronavirus (2019-nCoV) outbreak. J Travel Med 27(2):taaa020

Windfeld ES, Brooks MS-L (2015) Medical waste management-a review. J Environ Manag 163:98-108

World Health Organization (2020a) Modes of transmission of virus causing COVID-19: implications for IPC precaution recommendations: scientific brief, 27 March 2020.

World Health Organization (2020b) Water, sanitation, hygiene and waste management for COVID-19: technical brief, 03 March 2020.

Wu JT, Leung K, Leung GM (2020) Nowcasting and forecasting the potential domestic and international spread of the 2019-nCoV outbreak originating in Wuhan, China: a modelling study. Lancet 395(10225):689-697
Yadegaridehkordi E, Hourmand M, Nilashi M, Alsolami E, Samad S, Mahmoud M, Alarood AA, Zainol A, Majeed HD, Shuib L (2020) Assessment of sustainability indicators for green building manufacturing using fuzzy multi-criteria decision making approach. J Clean Prod 122905.

Yang Y, Li W, Zhang Q, Zhang L, Cheung T, Xiang Y-T (2020) Mental health services for older adults in China during the COVID-19 outbreak. Lancet Psychiatry 7(4):e19. https://doi.org/10.1016/ s2215-0366(20)30079-1

You S, Sonne C, Ok YS (2020) COVID-19's unsustainable waste management. Science 368(6498):1438

Yu H, Sun X, Solvang WD, Zhao X (2020) Reverse logistics network design for effective management of medical waste in epidemic outbreaks: insights from the coronavirus disease 2019 (COVID19) outbreak in Wuhan (China). Int J Environ Res Public Health 17(5): 1770

Zhang J, Zhang Y (2018) Carbon tax, tourism CO2 emissions and economic welfare. Ann Tour Res 69:18-30

Zhou D, Dai S-M, Tong Q (2020) COVID-19: a recommendation to examine the effect of hydroxychloroquine in preventing infection and progression. J Antimicrob Chemother

Zhu N, Zhang D, Wang W, Li X, Yang B, Song J, Zhao X, Huang B, Shi W, Lu R (2020). A novel coronavirus from patients with pneumonia in China, 2019. N Engl J Med 